\title{
The role of communication climate on the performance of PT. Lazada Express Bandung employees with work motivation as an intervening variable
}

\author{
Satia Sugiarto (a) ${ }^{a}$, Ivan Gumilar Sambas Putra $\oplus^{(b)}$ \\ (a,b) Faculty of Business and Management, Widyatama University, Bandung, Indonesia
}

\begin{tabular}{l} 
A R T I C L E IN F O \\
\hline Article history: \\
Received 07 June 2020 \\
Received in rev. form 08 August 2020 \\
Accepted 12 August 2020 \\
\hline Keywords: \\
Communication Climate, Motivation, \\
Employee Performance \\
JEL Classification: \\
H10
\end{tabular}

\begin{abstract}
A B S T R A C T
Human resources in a company will always communicate with each other. In this business world, nothing can be accomplished without communicating effectively with employers, employees, clients, suppliers, and customers. The purpose of this study is to analyse the influence of communication climate on motivation, to analyse the influence of motivation on employee performance, and the influence of communication climate on employee performance mediated by motivation. This study used descriptive analysis research methods and path analysis using SPSS version 25 software. The unit of analysis in this study were all employees of PT Lazada Express Bandung, so the population in this study were all employees totalling 52 people. The sampling method using a saturated sampling method so that the number of respondents as large as the population of 52 employees. The results showed that the climate of communication has an influence on employee motivation. The magnitude of the influence of the communication climate on employee performance is $79.60 \%$. and there is an influence between work motivation on employee performance and motivation does not mediate the effect of communication climate on employee performance.
\end{abstract}

(C) 2020 by the authors. Licensee SSBFNET, Istanbul, Turkey. This article is an open access article distributed under the terms and conditions of the Creative Commons Attribution (CC BY) license (http://creativecommons.org/licenses/by/4.0/).

\section{Introduction}

On the one hand, globalization has progressively led to market expansion and reduction of obstacles, but on the other hand, globalization has increased rapidly among business organizations today. Therefore, the business organizations try to at least maintain their market share. All current trends generally make the market unpredictable. Considering this fact today, the human resources became an added value and the valuable resource of the organization (Ionel et al., 2010). In increasing this capacity and advantage, organizations should provide motivation to its employees (Manzoor, 2012). The organization skills in managing and making human resources are the result of a competitive advantage (Sikora et al., 2014). Human resources have special priorities in the organization, thereby creating a supportive climate to improve the effectiveness of organizational performance (Ferris et al., 1998). As a result of strong competition, every business certainly uses a different strategy to be able to improve its performance (Llaci, 2010). In this case to keep the resources, especially human, will not be successful if they are not motivated to work. That is, to obtain the satisfied organization performance the major roles of the company is pushing what makes employees satisfied or motivated to do the work.

Human resources in a company will always be communicate with each other. In this business world nothing can be achieved without communicating effectively with employers, employees, clients, suppliers, and customers (Payne and Frow, 2006). In order to remain competitive in the full competition market, domestic or global, all production factors (i.e. humans, machines and materials) should be managed properly. Among the factors, the human resources quality is the biggest challenge because it is not easy to manage. Management is required to manage the resource quality either by providing motivation and good communication for the purpose achieving excellent performance. Effective organizational communication plays an important role in this challenge (Shoraj and Llaci, 2015). The employee motivation has impact on employee and effective organizational performance (Fomenky, 2015).

* Corresponding author. ORCID ID: 0000-0001-6970-9104

(C) 2020 by the authors. Hosting by SSBFNET. Peer review under responsibility of Center for Strategic Studies in Business and Finance. https://doi.org/10.20525/ijrbs.v9i5.788 
Organizations need motivated employees to survive (Dobre, 2013). This is because motivated employees are more productive thus help the organization survive. To be effective, managers need to understand what motivates employees in the context of the roles they perform. Motivating employees is perhaps the most complex function performed by a manager (Diefendorff and Chandler, 2011). It is important for any manager to understand the needs of employees and their priorities, and in turn, using a mixture of the best motivation to suit every situation. Communication can make employees feel valued and important part of the business. The importance of effective communication is highlighted by many motivational theories for improving performance. Other than that, communication has an important impact on an organization's working group to channel information and lead to better performance. Communication has an important role to shape employee motivation.

Organizational communication is defined as interaction with one another in the context of an organization (Shonubi and Akintaro, 2016). This communication includes activities to send and receive messages through the various layers of functional by channeling messages and discuss various topics of interest to a group of companies where the employee worked. Some studies emphasize that effective communication can improve organizational results, especially in terms of performance (Rajhans, 2012). As a managerial tool, communication is often used as a tool to share information with members, leaders, and relations to coordinate activities (Men, 2014).

Table 1: Factors that affecting employees' performance

\begin{tabular}{lll}
\hline No & Factors that affecting employees' performance & \\
\hline $\mathbf{1}$ & Motivation Factor & $\mathbf{( \% )}$ \\
\hline $\mathbf{2}$ & Satisfaction Factor & $30 \%$ \\
\hline $\mathbf{3}$ & Communication Factor & $25 \%$ \\
\hline $\mathbf{4}$ & Training and development & $20 \%$ \\
\hline
\end{tabular}

Therefore, given that organizational performance is a slightly complicated and multidimensional problem (Quinn and Rohrbaugh, 1983). This study is proposed to investigate the role of communication climate on employee's performance of PT. Lazada Express Bandung with work motivation as an intervening variable. To focus on what is expected of factors or issues that affect performance, the researchers conducted interviews with the Human Resources Department (HRD) of PT. Lazada Express Bandung with the presurvey results:

Based on the Table 1, work motivation factors occupy the first position by $30 \%$, satisfaction $25 \%$, communication $20 \%$, and training $15 \%$. While there are important things where the communication climate also has an impact on performance achievement, this is a drawback that employees are talking about. The communication climate is not very supportive in the implementation of work, especially those related to checking and delivery. Information is sometimes difficult to understand because two-way communication is not effective. The research question in this study are as follows:

1. Does communication have an influence on employee motivation?

2. Do motivation factors influence employee performance?

3. Do Communications affect employee performance through motivation variable as intervening variable?

\section{Literature Review}

\section{Conceptual Framework and Hypothesis Development}

\section{Communication}

Communication in an organization has a very important role because communication is needed to exchange information, exchange opinions, make plans, reach agreements, and implement decisions and send messages (Neves and Eisenberger, 2012). Therefore, when communication stops, organized activities will also run poorly. Newstrom (2014) defined communication as an acceptance of an idea, a feeling and an attitude verbal or non -verbal to produce a profitable response. Meanwhile, communication as a process where information is exchanged and can be understood by two or more people with aim to motivate the behavior. A communication refers to the exchange of information between the sender (source) and recipient (destination) so that it is received, understood and leads to action (Gomez, 2012). Neves (2012) argues that communication is the way by which a thought is transferred from one person to another. Communication has an important role in an organization because it is a process where each person or group shares and influences information with / to other people (or groups) so that both people (or groups) understand each other clearly.

Communication cannot be defined solely in psychological view which defined as a process where an individual transmits his or her stimulation. In the eyes of sociologists, communication is a mechanism through which human relationships come out and developed. In this research, communication is defined as the process of exchanging or sharing information, ideas and feelings between senders and recipients in an organization. A performance in this case can be measured from the intended output or results of the organization. 


\section{Motivation}

The more motivation transferred by an organization to an employee, the more awards will be given by the employee (Lee \& Bruvold, 2003). Therefore, the motivation is the desire inherent to encourage people to achieve the objectives of their own and objectives of the organization. According to Shoraj and Llaci (2015) Motivation is often portrayed as a goal to act or as a psychological process that causes altered behavior, direction, and persistence.

Meanwhile, Mathis and Jackson (2011) argued that motivation is an emotional state that has a tendency for action. This is based on social exchange and reciprocity. Therefore, motivation is changing progress that supports a person for the achieving purpose. Performance is the result of multiplying skills with motivation, which is reflected in the equation "Performance $=$ skill + motivation" (Vroom, 1964)

Based on the equation, performance is associated with at least four likelihood factors: (1) knowing what to expect, (2) having the skills to do the work, (3) being motivated to do the work, (4) working in an environment where motivation grows. Furthermore, People are motivated by intrinsic and extrinsic motives, where each of these two motivations has their own characteristics that distinguish them from each other (Van Dijk and Kluger, 2004).

According to Vroom (1964) the word motivation is a derivative of the Latin word "movere" which means "to move" that refers to internal strengths and depends on the needs of individuals to achieve company goals (Uzonna, 2013). According to these compositions of the terminology, the motivation starts with a motif that means something that causes it to act. According to Burton (2012), motivation triggers a person to act and can influence how the people act. The motivation is defined as an attribute that moves a person to do or not do something. Aarabi et al (2013) mentions motivation as the main reason for behaviors. Researchers have different opinions about intrinsic motivation and extrinsic motivation (Aamir et al., 2012). Intrinsic motivation is defined as the activities undertaken to seek satisfaction inherent in a person. This motivation encourages itself to face challenges in order to achieve the desired results without external pressure or coercion. While extrinsic motivation is an activity that is carried out exclusively for the purpose of getting a gift or a result where this activity is carried out for happiness solely and because of the desire to work hard (Gomez et al., 2012). While in the context of performance, motivation is associated with overall employee performance as a factor, element, or desire that encourages employees to pursue and achieve the objectives of the tasks that have been given in order to achieve company goals.

\section{Performance}

Organizational performance is the output or results of the organization measured against the company's goals and objectives. The performance of the organization can be categorized into two type: (a) financial performance, (b) sales performance. In recent years, many organizations have sought to manage organizational performance using a balanced scorecard method in which performance is treated and measured in various dimensions such as: (a) Financial performance, (b) Customer service, (c) Social responsibility (Arakal and Mampilly, 2013).

In the human resource literature (Gomez et al., 2012), it is widely recognized that workers' motivation leads to higher quality human resources in both private and public organizations and resulted in optimal performance. The performance has a strong relationship with strategic objectives. Management must link the communication to the resources for the success of the company's goals as something that must be managed to get good results for the organization. Moullin (2007) states that performance will provide information to assess the extent of an organization's excellence. The Organizations will produce good or bad results when there is no motivation. Whereas when there is motivation, organizations are brighter and experience growth with impressive results. This supports the popular notion of motivation which has a direct impact on workers' performance in their work. Employee performance is very dependent on how good (effective and efficient) their motivation. Also the good performance can be achieved if management establish good communication with employees to motivate them so that it is aligned with what the organization intended.

\section{Effect of communication on employee motivation}

Every human activity is basically driven by a motivation. Work motivation is defined as a condition or energy that directs employees to achieve the company goals. Nowadays, the development of communication is seen as one of the most dominant and important activities in the organization because it can motivate employees. The role of communication in organizations can provide motivation to employees directly with several communication factors, such as nonverbal communication, interpersonal leadership communication and communication climate. The nonverbal communication, interpersonal leadership communication and communication climate have an important role to shape employee motivation. Nonverbal communication has a slightly strong role in forming positive motivation for employees (Neves and Eisenberger, 2012). Its roles include body communication, face communication and eye communication. Leadership communication is based on the level of information satisfaction between management and employees. Transparency in communication can be measured by looking if the communication between supervisors and employees progress seamlessly (Shonubi and Akintaro, 2016).

$\mathrm{H}_{1}$ : Communication has an influence on work motivation 


\section{Effect of Motivation on Performance}

A motivation is responsible for someone to act (Burton, 2012). On the other hand, motivation is interpreted as an activity carried out exclusively to obtain goals. The definition of motivation in relation to employee performance can be simply defined as factors, elements, or desires that encourage employees to pursue and achieve work goals. Moreover, it can be the reason why employees act and behave in certain ways that can be influenced. In the human resource literature, it is widely recognized that the role of worker motivation leads to the higher quality of human resource and optimal performance of private and public organizations.

$\mathrm{H}_{2}$ : Employee motivation influences organizational performance

\section{Effect of Communication through motivation on performance}

A motivation will be realized well if it is based on well-established communication. Research by Shoraj and Llaci, (2015) show that good communication in the working environment will affect employee motivation at work. This shows that high motivation will be realized if it is established with effective communication. A high level of employee motivation will make it easier for the organization to achieve optimal performance (Shoraj and Llaci, 2015). The results from study by Shoraj and Llaci, (2015) stated that high motivation will be achieved by a good level of communication, while optimal performance can be achieved if managers or leaders establish good communication that can stimulate employee motivation.

$\mathrm{H}_{3}$. Communication influences performance with motivation as intervening.

\section{Methodology}

This research was conducted through quantitative research. This research is explanatory research that explains the causal relationship between testing various hypotheses. This study will use path analysis to build a model that occurs between the independent variable $(\mathrm{X})$ intervening variable $(\mathrm{Z})$ and the dependent variable (Y) (See Figure 2).

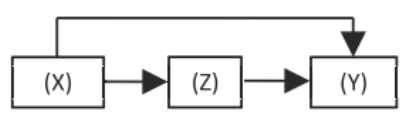

Figure 1: Path analysis

Where $\mathrm{X}=$ Communication, $\mathrm{Z}=$ Motivation, $\mathrm{Y}=$ Performance. The study population was all 52 permanent employees of PT Lazada Express Bandung. Because the total population of 52 employees used in this study, the research will be the study population while the technique to taking sample is by taking all populations. This research method was descriptive analysis and using Path analysis.

\section{Findings}

The respondent characteristics in PT Lazada Express Bandung were dominated by men with percentage of $87 \%$. The majority age was $<30$ years old equal to $58 \%$ and $67 \%$ of the employees had been working for $<5$ years.

The three variables are said to be valid and reliable if the indicator has a correlation value above 0.70 . However, in the development stage the loading scale was 0.50 to 0.60 which is still acceptable. Likewise, for reliability, Indicators are declared reliable if the composite reliability and Cronbach alpha values are above 0.70 .

Indicators in the communication climate variable were measured using 8 indicators that correlation values in the validity test showed the number $>0.50$ and for the reliability test $>0.70$ so that all indicators in the work environment variable showed valid and reliable. Likewise, the motivational variable measured by 11 indicators and employee performance measured using 6 indicators. Both also got valid and reliable results.

Based on the test results with the goodness-fit model test with the help of the Smart PLS software, R-Square values were as follows

Table 2: R- Square

\begin{tabular}{ll}
\hline Variable & R-Square \\
\hline Communication climate & \\
\hline Performance & 0.796041 \\
\hline Motivation & 0.773998 \\
\hline
\end{tabular}

Table 2 showed an R-square value of 0.796041 which meat the influence of the communication climate on the performance of PT Lazada Express Bandung employees was $79.60 \%$, while $20.4 \%$ was influenced by other factors that also affect the performance of PT Lazada's employees Bandung Express. Table 2. also explained the work environment model on motivation giving an R-Square value of 0.773998 meaning that the influence of the work environment on the motivation of employees of PT Lazada Express Bandung 
was $77.39 \%$, while the remaining $22.61 \%$ was influenced by other factors. Based on the results of testing with the t-test (hypothesis testing) using Smart PLS software, the results can be seen in Table 3.

Table 3: Results of Influence between Variables

\begin{tabular}{lllllc}
\hline & Connection Influence & $\begin{array}{l}\text { Original Sample } \\
(\mathbf{O})\end{array}$ & T-Stat & T-Table & Information \\
\hline $\mathbf{H}_{1}$ & Communication Climate $(\mathrm{X}) \rightarrow$ Motivation $(\mathrm{Z})$ & 0.517584 & 5.938326 & 2.00856 & Accepted \\
& & & & \\
\hline $\mathbf{H}_{2}$ & Communication Climate $(\mathrm{X}) \rightarrow$ Employee performance $(\mathrm{Y})$ & 0.879772 & 9.486594 & 2.00856 & Accepted \\
& & & & & \\
\hline $\mathbf{H}_{3}$ & Motivation $(\mathrm{Z}) \rightarrow$ Employee performance $(\mathrm{Y})$ & 0.402256 & 4.780430 & 2.00856 & Accepted
\end{tabular}

\section{Effect of communication climate on motivation}

The results of the estimated coefficient for the influence of the communication climate on motivation showed the value of 0.517584. The coefficient was positive which meant the better communication climate, the motivation will increase too. The statistical value of 5.938326 showed that there was a significant influence of communication climate variables on motivation. This was because the statistical value obtained from the calculation was greater than 2.00856. The magnitude of the communication climate influence on motivation was 77.39 \%. This study found that the communication climate at PT Lazada Express Bandung had a large influence on motivation. This was because the Climate Communications at PT Lazada Express Bandung had average score 3.40 (Conducive). It showed in high trust between employees with leadership and vice versa. Communication is an important element in organizational life, both in terms of administrative and management processes and the involvement of all parties in an organization. The results of this study were in line in (Neves and Eisenberger, 2012; Shonubi and Akintaro, 2016).

\section{Effect of Motivation on Employee Performance}

The effect of motivation on employee performance showed coefficient estimate value of 0.402256 which meant the positive influence between motivation and employees' performance. The coefficient was positive which means if employee motivation increases the employee's performance also increases. The statistic values was at 4.780430 which meant that motivation had a significant influence on employee performance. This could be seen in the PT Lazada Express Bandung's employees which feeling motivated, especially regarding salary, resulted the employees will further improve their performance. Therefore, at PT Lazada Express Bandung, employees will have good performance if supported by good motivation. The results of this study were in line with research in (Stella, 2008; Burton, 2012)

\section{The influence of the communication climate on employee performance through motivation}

The results of the estimated coefficient for the influence of the communication climate with employee performance indicate the estimated coefficient value of 0.517584 . the coefficient is positive which means the better the communication climate, the employee's performance will increase. The statistic value obtained was 9.486594 which meant the communication climate had a significant influence on employee performance. This was because the statistical value obtained from the calculation greater than 2.00856. The magnitude of the communication climate influenced on the employee performance amounted to $79.60 \%$. while direct and indirect effects could be seen in Table 4 .

Table 4: Indirect Influences

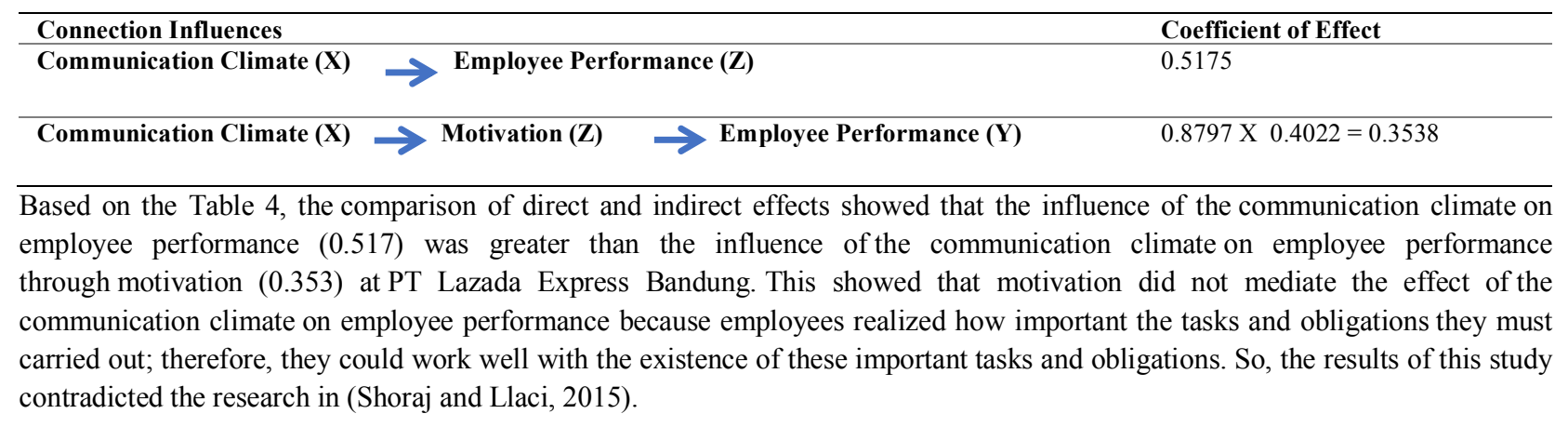

\section{Conclusions}

The communication climate has an influence on employee motivation. This shows that the communication climate at PT Lazada is indicated by the high level of mutual trust between employees and leaders and vice versa. Communication is an important element in organizational life, both in terms of administrative and management processes as well as the involvement of all parties in an organization. Work motivation affects employee performance. This shows that employees have high work morale, are satisfied, have 
high work productivity and always maintain stability in the work environment. The basic principle of management states that the performance of human resources is a combination of one's own motivation and ability to carry out a job. Motivation does not mediate the influence of the communication climate on employee performance.

\section{References}

Aamir, A., Jehanzeb, K., Rasheed, A., \& Malik, O. M. (2012). Compensation Methods and Employees' Motivation (With Reference to Employees of National Commercial Bank Riyadh). International Journal of Human Resource Studies, 2(3), 221-230.

Aarabi, M. S., Subramaniam, I. D., \& Akeel, A. B. A. A. B. (2013). Relationship between motivational factors and job performance of employees in Malaysian service industry. Asian Social Science, 9(9), 301-313.

Arakal, T., \& Mampilly, D. S. R. (2013). The Impact of Organizational Climate on Performance of Employees, 4, 1-12.

Burton, K. (2012). A study of motivation: How to get your employees moving. Management, 3(2), 232-234.

Diefendorff, J. M., \& Chandler, M. M. (2011). Motivating employees. In APA handbook of industrial and organizational psychology, Vol 3: Maintaining, expanding, and contracting the organization. (pp. 65-135). American Psychological Association.

Dobre, O. I. (2013). Employee motivation and organizational performance. Review of applied socio-economic research, 5(1), 53-60.

Ferris, G. R., Arthur, M. M., Berkson, H. M., Kaplan, D. M., Harrell-Cook, G., \& Frink, D. D. (1998). Toward a social context theory of the human resource management-organization effectiveness relationship. Human resource management review, 8(3), 235-264.

Fomenky, N. F. (2015, January). The impact of motivation on employee performance. In Global conference on business \& finance proceedings (Vol. 10, No. 1, p. 332). Institute for Business \& Finance Research.

Gomez-Mejia, L. R., Balkin, D. B., \& Cardy, R. L. (2012). Managing Human Resources. United State: Pearson Educaion.

Ionel, V. C., Alina, C., \& Dumitru, M. I. (2010). Human resources accounting accounting for the most valuable asset of an enterprise. Annals of the University of Oradea: Economic Science, 1(2), 925-931.

Lee, C. H., \& Bruvold, N. T. (2003). Creating value for employees: investment in employee development. The International Journal of Human Resource Management, 14(6), 981-1000.

Manzoor, Q. A. (2012). Impact of employees motivation on organizational effectiveness. Business management and strategy, 3(1), $1-12$.

Mathis, R. L., \& Jackson, J. H. (2011). Human resource management: Essential perspectives. New York: Cengage Learning.

Men, L. R. (2014). Why leadership matters to internal communication: Linking transformational leadership, symmetrical communication, and employee outcomes. Journal of Public Relations Research, 26(3), 256-279.

Moullin, M. (2007). Performance measurement definitions. International journal of health care quality assurance, 20(3), 181-183.

Neves, P., \& Eisenberger, R. (2012). Management communication and employee performance: The contribution of perceived organizational support. Human performance, 25(5), 452-464.

Newstrom, J. (2014). Organizational behavior: Human behavior at work. New York: McGraw-Hill Higher Education.

Payne, A., \& Frow, P. (2006). Customer relationship management: from strategy to implementation. Journal of Marketing Management, 22(1-2), 135-168.

Rajhans, K. (2012). Effective organizational communication: A key to employee motivation and performance. Interscience Management Review, 2(2), 81-85.

Shonubi, A. O., \& Akintaro, A. A. (2016). The impact of effective communication on organizational performance. The International Journal of Social Sciences and Humanities Invention, 3(3), 1904-1914.

Shoraj, D., \& Llaci, S. (2015). Motivation and its impact on organizational effectiveness in Albanian businesses. Sage Open, 5(2),

Sikora, D. M., Thompson, K. W., Russell, Z. A., \& Ferris, G. R. (2016). Reimagining overqualified human resources to promote organizational effectiveness and competitive advantage. Journal of Organizational Effectiveness: People and Performance, 3(1), 23-42.

Stella, O. (2008). Motivation and work performance: Complexities in achieving good performance outcomes; A study focusing on motivation measures and improving workers performance in Kitgum district local government. Institute of Social Studies, $1-83$.

Quinn, R. E., \& Rohrbaugh, J. (1983). A spatial model of effectiveness criteria: Towards a competing values approach to organizational analysis. Management science, 29(3), 363-377.

Van-Dijk, D., \& Kluger, A. N. (2004). Feedback sign effect on motivation: Is it moderated by regulatory focus?. Applied Psychology, 53(1), 113-135.

Vroom, V. (1964). Expectancy theory. Work and motivation, London: John Wiley. 